\title{
A Design on the Information Platform of Agricultural Products Logistics
}

\author{
Jie ZHU \& Binbin FU \& Chunlin ZHANG \\ School of Information, Beijing Wuzi University, Beijing, China, 101149
}

\begin{abstract}
The informatization of agricultural products logistics (APL) is an objective requirement with the development of agricultural modernization. This paper briefly analyzes domestic and foreign APL, and we suggest a scheme of building logistics information platform taking the situation of Henan province (In the central of China) as an example. Considering the demand of analysis on the platform, the structure, hierarchy and function of the platform are designed by the principle of building an information platform. With the example of Henan province, we hope it could provide theoretical and practical guidance for others constructions of APL platform.
\end{abstract}

KEYWORD: Agricultural products; Logistics; agricultural products logistics (APL); information platform

\section{PREFACE}

Logistics is engaged into our daily life as a very important service, and agricultural products, such as fruits, vegetables, and fresh food are the essential elements in our lives.APL, through a set of logistics activity, transfers agricultural products from the origin to the consumer. China is an agricultural country with large population, and the origins of agricultural product are often far away from supply places, so APL is vital to our country, though APL is just a small branch in logistics system.

The methods to improve the circulation efficiency of the existing agricultural product, increase logistics corporate profits, and achieve node win-win on logistics supply chain, are always the research topics of enterprises, the logistics industries, and the government departments.

\subsection{Current situation of Agricultural products logistics domestic and abroad}

The study of APL develops nearly a decade in China, and also due to the APL related to the Chinese people's livelihood, it gets highly attended. The study of APL by Experts and scholars mainly includes: APL theory, the circulation of APL, APL development strategy, logistics development mode, etc. With expansion of the scope of study and deepening of the research content, there have been significant research results, and gained good effect in practical applications [1].
Wang Zhitai [2] who is the early analyst on China APL, provides the significance of developing APL mainly from the view of industrial environment. Jia Weili [3] focuses on the supply and demand of agricultural products in China, and analyzed the existing supply and demand imbalance. He found out the reasons for this phenomenon and provided the corresponding solutions. Li Xiaojin [4] from the view of professional development promoted the development of APL information construction.

The study of APL in other countries is synchronized with the whole logistics industry. Compared to others logistics industry, agricultural products have no obvious difference, so the research of agricultural products logistics is the study of the whole industry [5]. In the late 90s, Monezka, Trent and Handifield [6] (1998) defined the supply chain as the sum of activities from raw materials procurement, to enterprise's production and processing, and to includes transportation, warehousing, distribution processing, packaging, product distribution to the final consumer. Afterwards, Castle and Lee, made the new thinking that put combined simulation system with financial analysis in the supply chain management model. This point appeared, makes managers realize that logistics management not only rely on unilateral efforts, but also depend on cooperation of suppliers, enterprises, consumers and third party logistics. 


\subsection{Informationization development of Agricultural products logistics}

With the popularization of information technology, and with the B2B and B2C mode, online supermarkets, chain stores and other modern methods fundamentally promote the development of the agricultural market. Logistics informationization is the essential characteristics of modern APL, and makes modern APL different from traditional one. Logistics Informationization uses modern information technology to logistics, cash flow, information flow and other resources integration. It is used to construct logistics information platform and promote the development of modern APL industry. The research on informatization is related with logistics industry.

Yi Quan [7], etc in an article of $A$ research onthe construction of Yangtze River main line logistics information platform, analyzes on the Yangtze river main line feasibility and necessity of constructing the EDI system, and then finally puts forward some Suggestions of EDI system construction. Fu Lan [8] in APL information system design pointed out that in order to realize the modernization of APL, logistics information system construction is the important means, according to the function of APL system, where she divided into seven subsystems. Through the construction of public information platform and function modules with mutual cooperation, the information is sharing between the two sides of supply and demand. Cui Man, Lu Jianjun, Zhao Anxin, Wei Chen [9] from the Internet of things technology, found the low efficiency of logistics and the low degree of information sharing in the existence of coal enterprise, and propose to establish the information platform to enhance information feedback speed and information sharing degrees.

\section{DEMAND OF APL INFORMATION PLATFORM}

Agricultural production is the main economic industry in Henan Province located in the central region of country where it has convenient transportation. This paper gives, taking Henan province as an example, a brief analysis and design of APL information platform.

\subsection{Development Status of APL informationization in Henan}

Compared with developed countries, and domestic economic developed regions, in aspect of infrastructure, information standards, new technology applications, logistics platform construction and talents training, Henan Province falls behind a huge gap, which mainly reflected in the following aspects:
(1) Logistics information disconnect, and difficult to trace agricultural product quality safety problems.

(2) Poor infrastructure, difficult to establish a unified standard data and collect information.

(3) Logistics information is isolated.

\subsection{Analysis development of APL with SWOT method}

\begin{tabular}{|c|c|}
\hline$S$ & $\begin{array}{l}\text { Geographical: a transportation hub for rail, } \\
\text { road and aviation for domestic lines of north- } \\
\text { south and east-west. } \\
\text { Resources: the largest grain production base, } \\
\text { the second fruit and vegetable production. } \\
\text { Information network: based on Internet, } \\
\text { broadband network information platform is } \\
\text { constructing to be perfected. } \\
\text { Policy: the local government issued some } \\
\text { support policies. }\end{array}$ \\
\hline W & $\begin{array}{l}\text { Logistics management: there is no unified } \\
\text { management, and different departments } \\
\text { manage their own section, and also division of } \\
\text { labor and responsibility is not clear. } \\
\text { Circulation: unprocessed primary products } \\
\text { occupy a large share, and it does not bring } \\
\text { value-added benefits; circulation too much, } \\
\text { causing an increase in costs } \\
\text { IT backward: poor infrastructure and } \\
\text { technology development lags behind. }\end{array}$ \\
\hline $\mathrm{O}$ & $\begin{array}{l}\text { Henan province established a modern logistics } \\
\text { industry development planning in Henan } \\
\text { province (2012-2015). } \\
\text { Relying on a large circulation enterprises and } \\
\text { wholesale markets, developing agricultural } \\
\text { logistics, and supporting agricultural goods } \\
\text { storage and distribution system in the province, } \\
\text { to promote the development of logistics } \\
\text { industry [10]. }\end{array}$ \\
\hline $\mathrm{T}$ & $\begin{array}{l}\text { Unlike other commodities, processing and } \\
\text { transportation have requirements on time and }\end{array}$ \\
\hline
\end{tabular}

\section{THE FUNCTION DESIGN OF THE AGRICULTURAL PRODUCTS LOGISTICS INFORMATION PLATFORM}

According to the characteristics of APL in Henan province, the specific function of platform has carried on the detailed design. 


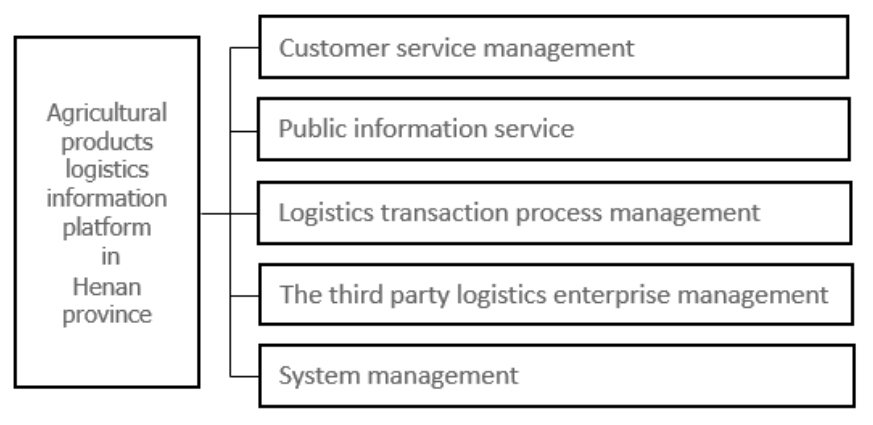

Figure 1 Function model of Henan agricultural products logistics information platform

\subsection{Customer service management}

The function of the user service mainly includes the business entity registration, information release, services information query, safety certification, etc. Business entity registration refers to the third party logistics enterprise registered in platform, and it gets access permission and logistics information of supply and demand according to the standardized form. Safety certification is mainly used to protect the user's information security.

\subsection{Public information service}

The public information service includes recommendation and evaluation for third party logistics enterprise, dissemination of the latest industry information, release of relevant policy laws and regulations and service rules. Recommendation and evaluation mainly rank customer service satisfaction in terms of the enterprise scale, service ability, customer feedback, and many other factors, and then the results were announced.

\subsection{Logistics transaction process management}

Logistics transaction management is one of the important function, and it includes logistics demand management, optimization logistics solution, and order information management. The order management tracks four modules.

Logistics demand management refers to provide customers with logistics demand information, and updates the demand information in time, to improve the efficiency of the transmission of information. Optimization logistics solution, through the different logistics needs of customers, provides the corresponding scheme solution. Services include the choice of suppliers, optimization of the path, the choice of transportation mode, and so on. Order information management namely is something about shopping online. After ordering, customers login the platform to query subsequent order execution status, where order tracking can tell real-time path information.

\subsection{The third party logistics enterprise management}

The management of the third party logistics enterprise mainly includes basic information management, service index evaluation system, membership fees to pay, credit evaluation function [10].

\subsection{System management}

System management is mainly composed of service information query, system initialization, rights management, role management, daily information maintenance and so on.

\section{THE STRUCTURE DESIGN OF AGRICULTURAL PRODUCTS LOGISTICS INFORMATION PLATFORM}

\subsection{The basic structure of platform}

By the demand analysis and function orientation for APL information platform, it constructs the framework of Henan APL information platform structure, as shown in Figure 2.

The design of platform is based on the features of the agricultural products, with the characteristics of a high degree of information integration. The platform loads a big data process, for the user to build a virtual trading environment, to provide logistics participants with information query and back-ground support functions.

\subsection{The platform architecture}

(1) The base layer. Through the geographic information system, it collects logistic original data, which is the foundation for other business development levels.

(2) The management of industry layer. Every profession has its own unique information processing system, such as road administration information system of transport industry, and electronic settlement systems of insurance, and taxation industry. Making standardized treatment for each information platform and then realizing information sharing. 


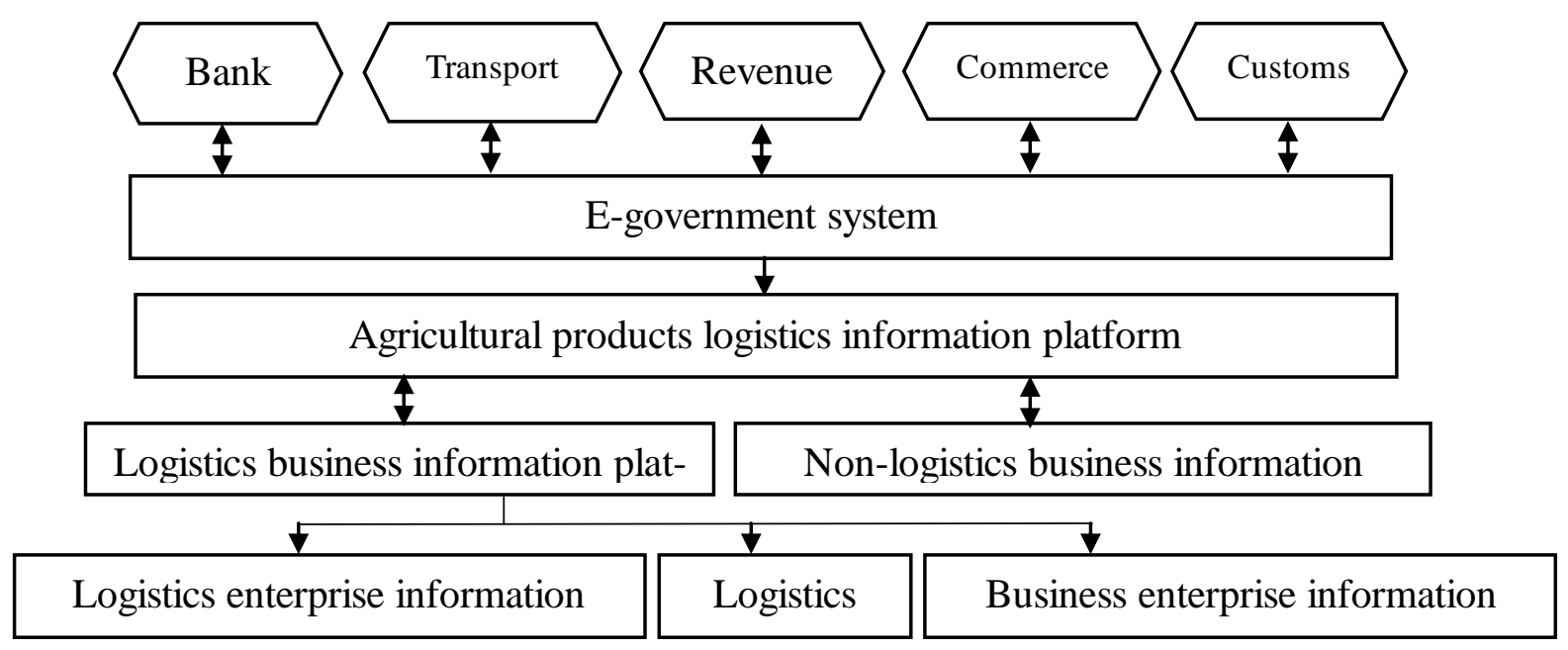

Figure 2 Basic framework of Henan agricultural products logistics information platform

(3) Information control layer. Information service center is taken as a technical support and control center, which takes data maintenance and operation management tasks. By the public information platform, Information service center provided the enterprise layer with information value-added services.

(4) Enterprise layer. It is composed of supply, demand and the third party logistics enterprise. On the logistics information platform, it releases query information, and realizes the paperless trade and electronic office.

\section{CONCLUSION}

From the perspective of industrial development based on Henan province, this paper analyses the development status of APL, and it does function analysis and structure design for APL information platform. This is the key to information platform construction for integrating the logistics resources, and for further enhancing the competitiveness of regional economy [11].This paper provides a certain theoretical basis and technical support to construct a regional level information platform.

\section{ACKNOWLEDGEMENT}

This research is supported by the Beijing Key Laboratory.

\section{REFERENCES}

[1] Du Liqing. A research of the development of Chinese agricultural products logistics system (D)

[2] Wang Zhitai. Modern logistics. Beijing: China supplies publishing house, 1995, 12 - 15.

[3] Jia Weili. On the supply and demand analysis and countermeasures of agricultural products logistics. Journal of Anhui agricultural university, 2004, (3): 52-56.

[4] Li Xiaojin. Agricultural products industry logistics system construction and related technology. 2009, (11): 62.

[5] Yu Zhihua. A research on the agricultural products logistics domestic and abroad (2010), 12-0051-03

[6] Monczk.r: trent.r and handheld. purchasing and supply chain management, south-westren college publishing, 1998, 25-30.

[7] Yi Quan. A research on the construction of Yangtze River main line logistics information platform, Journal of logistics technology, 2007, (2): 36 to 38 .

[8] Fu Lan. Agricultural products logistics information system design. Circulation economy in China, 2009, (9): 32-35.

[9] Cui Man, Lu Jianjun, Zhao Anxin, Wei Chen. Coal enterprise logistics information platform based on the Internet of things application study. Journal of coal technology, 2012, 1 (30): 243-245.

[10] Modern logistics industry development planning in Henan province (2010-2015) years [EB/OL]. [2010-04-21]. http://www.henan.gov.cn/zwgk/system/2010/04/21/01019 0213.shtml

[11] Zhou Zhijun. Development trend of regional logistics public information platform technology. Journal of China's manufacturing industry informationization, 2010 (1): 64-67. 